\title{
GAMBARAN PENGETAHUAN WANITA USIA SUBUR TENTANG MANFAAT IVA TEST
}

\author{
Fardila Elba ${ }^{1}$, Imma Kristy Nathalia ${ }^{2}$ \\ fardilaelba@yahoo.com \\ ${ }^{1}$ Departemen Kesehatan Masyarakat, Fakultas Kedokteran, Universitas Padjadjaran; \\ ${ }^{2}$ Program Studi Diploma Kebidanan Fakultas Kedokteran Universitas Padjadjaran
}

\begin{abstract}
The incidence of cervical cancer in Indonesia is quite high at 25.91\%. Cervical cancer can be detected early with VIA test. VIA test is one of the first steps to detect abnormalities in the cervix. VIA test is an easy check, cheap, and can be done by the midwife. However, the coverage of VIA test in Indonesia is still low about $2.45 \%$ of the target coverage determined by the government that is $80 \%$. The low coverage of VIA test screening in Indonesia is influenced by the low knowledge of women. Women's low knowledge will influence their participation in screening. This research uses crosssectional method approach. The sample in this study is Women of Childbearing Age aged 15-49 years in the working area of Puskesmas Soreang. Sampling uses proportional stratified random sampling technique with a sample size of 76 respondents. Data analysis uses Fisher Exact Test. The results show that there is a significant relationship between knowledge and attitude of WUS with $p$ value = 0.000 ( $p>0.005$ ). Based on the results of this study, it can be concluded that there is a relationship between knowledge and attitude of WUS on VIA test for early detection of cervical cancer.
\end{abstract}

Keywords: VIA test, Cervical Cancer, Knowledge, Attitude

\section{PENDAHULUAN}

Wanita Usia Subur (WUS) adalah wanita dengan organ reproduksi dalam keadaan baik serta berada pada rentang umur antara 15 - 49 tahun. Menurut data Kementrian Kesehatan Republik Indonesia tahun 2015, jumlah WUS yang berada di Indonesia yaitu 69.195.283 dan di wilayah Jawa Barat yaitu 12.749.261. Kelompok WUS rentan terhadap beberapa permasalahan diantaranya anemia gizi besi, obesitas, kanker payudara, kanker serviks dan masalah-masalah lainnya. Salah satu masalah yang dapat terjadi pada WUS adalah kanker serviks. ${ }^{1,2}$

Kanker serviks merupakan kanker primer dari serviks yang berasal dari metaplasia epitel peralihan mukosa vagina dan mukosa kanalis servikalis yaitu pada daerah Sambungan Skuamo-Kolumnar (SSK). Menurut data World Health Organization (WHO), terjadi peningkatan insiden kanker dari 12,7 juta kasus pada tahun 2008 menjadi 14,1 juta kasus tahun 2012. Berdasarkan data yang didapat dari Globocan, International Agency for Research on Cancer (IARC) tahun 2012, insiden kejadian kanker serviks $8,8 \%$ dan jumlah kematian yang disebabkan kanker serviks yaitu $8,2 \%$ dari seluruh jumlah kanker pada seluruh wanita di dunia. Di Indonesia, prevalensi kanker cukup tinggi. Angka kejadian kanker serviks di Indonesia yaitu sebanyak $25,91 \%$. Kanker 
tertinggi di Indonesia pada wanita adalah kanker payudara dan kanker serviks. Jumlah penderita kanker serviks di Jawa Barat yaitu $0,7 \%$ atau 15635 wanita. $^{2-4}$

Kanker serviks disebabkan oleh Human Pappiloma Virus (HPV), sub tipe onkogenik terutama sub tipe 16 dan 18 . Perkembangan kanker serviks dimulai dari lesi abnormal hingga menjadi karsinoma invasif membutuhkan waktu $4-27$ tahun. Perkembangan yang membutuhkan waktu cukup lama dari sel yang terinfeksi menjadi kanker serviks memberikan kesempatan bagi Wanita Usia Subur (WUS) untuk dapat melakukan deteksi kanker serviks sedini mungkin. Oleh karena itu, penting bagi wanita melakukan pencegahan untuk menekan angka kejadian kanker serviks seperti melakukan pola hidup sehat, menghindari faktor risiko yang dapat menyebabkan kanker serviks, melakukan imunisasi HPV, dan diikuti dengan melakukan deteksi dini kanker serviks melalui pemeriksaan pap smear maupun IVA test. ${ }^{5}$

IVA test (Inspeksi Visual dengan menggunakan Asam Asetat) adalah metode penapisan yang murah, efektif, dan dapat dilakukan oleh bidan. IVA test merupakan pemeriksaan secara inspekulo yang dilakukan dengan mata telanjang terhadap leher rahim yang telah diberi asam asetat 3-5\%. ${ }^{6}$ Pemeriksaan IVA test dapat mendeteksi dini kanker serviks dengan cara membedakan leher rahim normal dan abnormal untuk mengidentifikasi lesi pra kanker. Namun, cakupan skrining kanker serviks menggunakan IVA test di Indonesia masih sangat rendah sekitar $2,45 \%$ dari cakupan target untuk menurunkan angka kesakitan dan kematian karena kanker serviks yaitu $80 \%$. Dari penelitian sebelumnya pada tahun 2014 diketahui bahwa cakupan untuk melakukan deteksi dini kanker serviks dengan IVA test kurang dari 5\%. Salah satu hal yang menyebabkan cakupan IVA test rendah adalah pengetahuan WUS. ${ }^{6,7}$

Pengetahuan merupakan hasil dari tahu yang terjadi melalui proses sensoris khususnya mata dan telinga terhadap objek tertentu. Pengetahuan dipengaruhi oleh beberapa faktor diantaranya tingkat pendidikan, umur, pekerjaan, serta informasi. ${ }^{8}$ Faktor pendidikan memiliki hubungan yang bermakna dengan tingkat pengetahuan seseorang. Selain pendidikan, umur yang bertambah dapat meningkatkan pengetahuan seseorang karena pengetahuan bisa didapat dari pengalaman dan berbagai informasi. ${ }^{9}$ Pengetahuan wanita yang baik mengenai kanker serviks dapat mempengaruhi tindakan untuk melakukan deteksi dini, dengan pengetahuan yang baik wanita diharapkan dapat mengetahui, memahami, menganalisis, mensintesis, serta menilai 
apakah pemeriksaan IVA test perlu dilakukan untuk mendeteksi dini terjadinya kanker serviks. Namun saat ini pengetahuan WUS masih termasuk dalam kategori rendah. ${ }^{10}$

Tingkat pengetahuan dalam kategori rendah yang dimiliki oleh WUS akan mempengaruhi partisipasinya dalam melakukan skrining, karena pengetahuan merupakan salah satu faktor yang dapat mempermudah perubahan sikap seseorang (predisposing factor). Sikap merupakan respon terhadap stimulus atau objek yang telah melibatkan pendapat dan emosi seseorang. Dengan sikap yang baik diharapkan seorang wanita dapat menerima, merespon, hingga bertanggung jawab mengenai kesehatan dirinya sehingga muncul kesadaran untuk melakukan deteksi dini kanker serviks salah satunya dengan menggunakan IVA test. $^{11}$ Beberapa penelitian menunjukan bahwa sikap dan perilaku WUS terhadap pemeriksaan IVA test masih rendah karena masih banyak WUS yang belum pernah melakukan pemeriksaan IVA test. Kesadaran WUS yang rendah dipengaruhi oleh pengetahuan yang dimiliki, karena pengetahuan merupakan domain yang penting untuk terbentuknya tindakan seseorang. Mengingat angka kejadian kanker serviks dapat ditekan dengan menghindari faktor risiko dan melakukan deteksi dini, pengetahuan WUS tentang kanker serviks sangatlah penting. Dengan pengetahuan yang baik diharapkan wanita dapat menghindari faktor risiko dan melakukan deteksi dini kanker serviks salah satunya dengan pemeriksaan IVA test.

\section{METODE PENELITIAN}

Penelitian ini telah dilakukan pada bulan Juni 2017 sampai dengan Juli 2017 di Soreang Kabupaten Bandung. Populasi yang digunakan dalam penelitian ini adalah Wanita Usia Subur (WUS) di 6 desa wilayah kerja Puskesmas Soreang yang berjumlah 17801. Penelitian ini menggunakan metode analitik dengan pendekatan potong silang (cross sectional). Sampel dalam penelitian ini diambil dengan menggunakan teknik proportionate stratified random sampling di 6 desa wilayah kerja Puskesmas Soreang. Sampel pada penelitian ini adalah WUS di wilayah kerja Puskesmas Soreang yang telah memenuhi kriteria inklusi dan eksklusi. Besar sampel dihitung dengan menggunakan rumus yaitu:

$$
\mathrm{n}=\mathrm{z}^{2} \mathrm{PQ} / \mathrm{d}^{2}
$$

\section{Keterangan:}

$\mathrm{n} \quad=$ ukuran sampel

$\mathrm{Z}=$ standar deviasi normal

$\mathrm{P} \quad=$ proporsi suatu masalah

$\mathrm{Q} \quad=1-\mathrm{P}$

$\mathrm{d}=$ derajat akurasi 
Tingkat kepercayaan dalam penelitian ini adalah 95\%. Proporsi besarnya masalah dari penelitian sebelumnya yaitu $5 \%$. Berdasarkan hasil perhitungan menggunakan rumus tersebut, didapatkan jumlah sampel sebesar 76 orang. Kriteria inklusi yang ditetapkan yaitu WUS yang berusia antara 15-49 tahun yang telah menikah, WUS yang berdomisili di wilayah kerja Puskesmas Soreang, dan WUS yang bersedia menjadi responden. Sedangkan kriteria eksklusi penelitian ini adalah wanita yang diketahui menderita kanker serviks.

Data yang digunakan pada penelitian ini adalah data primer dengan menggunakan instrumen berupa kuesioner dengan pernyataan tertutup. Kuesioner yang diberikan dibuat oleh peneliti dan diberikan secara langsung kepada responden. Kuesioner terdiri dari dua bagian yaitu kuesioner untuk mengukur pengetahuan yang terdiri dari 25 pernyataan dan kuesioner untuk mengukur sikap yang terdiri dari 14 pernyataan. Kuesioner tersebut telah diuji validitas dan reliabilitas pada 30 responden. Hasil yang didapat dari kuesioner akan diangkakan, disusun, dan dianalisa secara statistik untuk menarik kesimpulan penelitian.

Pada penelitian ini analisis data yang dilakukan menggunakan bantuan program komputerisasi meliputi analisis univariat dan bivariat. Analisis univariat bertujuan untuk mengetahui gambaran variabel pengetahuan dan sikap WUS, sedangkan analisis bivariat bertujuan untuk mengetahui apakah terdapat hubungan antara variabel pengetahuan dengan sikap WUS terhadap pemeriksaan IVA test. Normalitas distribusi data dianalisis dengan metode analitik KolmogorovSmirnov karena jumlah sampel lebih dari 50. Jika hasil uji normalitas menunjukan $\mathrm{p}$ $>0,05$, maka sebaran data disebut normal. Analisis bivariat yang digunakan adalah Uji Fisher Exact. Pengolahan data tersebut menggunakan SPSS versi 20. Penelitian ini telah mendapatkan izin dari Komite Etik Fakultas Kedokteran Universitas Padjadjaran dengan nomor izin etik 559/UN6.C10/PN/2017.

\section{HASIL DAN PEMBAHASAN}

Tabel 1

Distribusi Frekuensi Karakteristik Responden

\begin{tabular}{cc}
\hline $\begin{array}{c}\text { Karakteristik } \\
\text { Responden }\end{array}$ & f \\
\hline Kelompok Usia & \\
\hline$<20$ tahun & 6 \\
$20-35$ tahun & 37 \\
$>35$ tahun & 33 \\
\hline Pekerjaan & \\
Bekerja & 27 \\
Tidak Bekerja & 49 \\
\hline Pendidikan & \\
Terakhir & 7 \\
SD & 21 \\
SLTP & 43 \\
SLTA & 5 \\
Peguruan Tinggi &
\end{tabular}


Berdasarkan tabel di atas tampak usia responden antara 20 - 35 tahun dan $>35$ tahun tidak jauh berbeda, tetapi masih terdapat 6 responden yang berusia kurang dari 20 tahun. Dalam penelitian ini didapatkan lebih banyak responden yang tidak bekerja dibandingkan dengan responden yang bekerja. Dilihat dari tingkat pendidikan, sebagian besar responden berpendidikan SLTA dan terdapat sebagian kecil responden yang berpendidikan SD.

Tabel 2

Tingkat Pengetahuan Berdasarkan Karakteristik Responden

\begin{tabular}{cccc}
\hline $\begin{array}{c}\text { Karakteristik } \\
\text { Responden }\end{array}$ & $\begin{array}{c}\text { Baik } \\
\text { f }\end{array}$ & $\begin{array}{c}\text { Pengetahuan } \\
\text { Cukup } \\
\text { f }\end{array}$ & $\begin{array}{c}\text { Kurang } \\
\text { f }\end{array}$ \\
\hline Kelompok Usia & & & \\
\hline$<20$ tahun & 2 & 4 & 0 \\
20-35 tahun & 10 & 25 & 2 \\
$>35$ tahun & 13 & 15 & 5 \\
\hline Pekerjaan & & & \\
\hline Bekerja & 11 & 13 & 3 \\
Tidak Bekerja & 14 & 31 & 4 \\
\hline Pendidikan Terakhir & & & \\
\hline SD & 1 & 5 & 1 \\
SLTP & 5 & 15 & 1 \\
SLTA & 17 & 21 & 5 \\
Peguruan Tinggi & 2 & 3 & 0 \\
\hline
\end{tabular}

Sumber: Data Primer

Berdasarkan tabel di atas, responden yang memiliki tingkat pengetahuan cukup paling banyak berada pada kelompok usia 20-35 tahun yaitu 25 responden, 31 dari 44 responden yang memiliki pengetahuan cukup tidak bekerja, dan 21 dari 44 responden yang memiliki pengetahuan cukup berpendidikan terakhir SLTA.

Hasil penelitian menunjukan bahwa sebagian besar responden memiliki pengetahuan yang cukup mengenai pemeriksaan IVA test. Pengetahuan yang cukup dapat diperoleh dari berbagai sumber, seperti: media massa (cetak dan elektronik), buku-buku, serta informasi yang didapat dari petugas kesehatan. Hasil jawaban kuesioner yang memiliki jawaban benar terbanyak adalah pernyataan yang membahas mengenai faktor risiko kanker serviks, penyebab kanker serviks, dan pengertian kanker serviks. Sedangkan yang memiliki jawaban salah terbanyak adalah pernyataan yang membahas mengenai tujuan pemeriksaan IVA test dan manfaat pemeriksaan IVA test. ${ }^{12-14}$

Pada salah satu pernyataan dalam kuesioner, sebagian besar responden menjawab salah dan beranggapan bahwa IVA test merupakan pemeriksaan yang dapat mengobati kanker serviks. Hal ini menunjukan bahwa responden memiliki pengetahuan yang cukup baik mengenai 
kanker serviks namun sebagian besar responden belum mengetahui bahwa kanker serviks dapat di deteksi dini dengan menggunakan pemeriksaan IVA test. ${ }^{6}$ Hasil penelitian ini sejalan dengan penelitian Chinthia (2015) bahwa pengetahuan yang baik mengenai kanker serviks diperoleh dari media massa maupun orang per orang namun masih terdapat banyak wanita yang kurang memahami mengenai metode untuk deteksi dini kanker serviks karena kurangnya informasi yang diperoleh tentang hal tersebut. Sebagian besar responden dalam penelitian ini mengatakan bahwa belum pernah menerima informasi mengenai pemeriksaan IVA test. ${ }^{11,15}$

Hasil penelitian ini sejalan dengan penelitian yang dilakukan oleh Lestari (2016) dan Mirayashi (2014) yang menyatakan bahwa sebagian besar responden memiliki pengetahuan yang cukup mengenai kanker serviks dan pemeriksaan IVA test. Pada penelitian tersebut Lestari menyebutkan bahwa tingkat pengetahuan yang cukup dipengaruhi oleh tingkat pendidikan responden terbanyak yaitu SMA. Hal tersebut sesuai dengan hasil penelitian ini yang menunjukan bahwa sebagian responden berpendidikan SLTA. Tingkat pendidikan seseorang dapat mendukung atau mempengaruhi cara pandang seseorang dan akan mempermudah proses penerimaan informasi serta nilai-nilai baru. Semakin tinggi tingkat pendidikannya, semakin mudah seseorang menerima informasi yang didapatkannya. Namun tingkat pendidikan belum tentu mempengaruhi tingkat pengetahuan karena pengetahuan juga dapat dipengaruhi oleh faktor lainnya seperti intelegensia, minat, umur, dan pekerjaan. ${ }^{15-17}$

Hasil penelitian menunjukan bahwa terdapat $32.9 \%$ responden yang memiliki pengetahuan baik, 13 dari 25 responden yang memiliki pengetahuan baik berusia lebih dari 35 tahun. Usia merupakan salah satu faktor yang mempengaruhi pengetahuan. Semakin bertambahnya usia seseorang maka akan terjadi perubahan aspek fisik dan psikologis yang membuat proses berpikirnya semakin matang, terjadi peningkatan dan perkembangan daya tangkap serta pola berpikir sehingga pengetahuan yang diperolehnya semakin baik. $^{9}$

Hasil penelitian menunjukan bahwa terdapat $9.2 \%$ responden yang memiliki pengetahuan yang kurang. Dari hasil penelitian tampak 4 dari 7 responden yang memiliki pengetahuan kurang tidak bekerja. Bekerja merupakan salah satu faktor yang dapat memudahkan seseorang memperoleh pengalaman dan pengetahuan baik secara langsung maupun tidak langsung. Namun pekerjaan tidak bisa 
dijadikan patokan untuk memperoleh informasi, karena terdapat beberapa pekerjaan yang kurang memberi kesempatan bagi wanita untuk memperoleh informasi tentang deteksi dini kanker serviks menggunakan metode IVA test. $^{18,19}$

Faktor lain yang menyebabkan kurangnya pengetahuan adalah kurangnya informasi yang diperoleh responden. Kurangnya informasi yang diperoleh dapat mempengaruhi tingkat pengetahuan yang dimiliki oleh responden. Seseorang yang memiliki sumber informasi yang lebih banyak akan memiliki pengetahuan yang lebih luas pula. Menurut Eva (2014), masih banyak wanita yang belum memahami mengenai apa maksud, tujuan, dan manfaat dari pemeriksaan IVA test. Hal tersebut dipengaruhi oleh tingkat pendidikan, pekerjaan, usia, serta informasi yang diperoleh. ${ }^{12}$

\section{KESIMPULAN}

Berdasarkan hasil penelitian dapat dibuat simpulan sebagian besar responden $(57,9 \%)$ memiliki pengetahuan yang cukup tentang manfaat pemeriksaan IVA test. Saran pada penelitian ini adalah diharapkan fasilitas kesehatan tingkat primer menyediakan sarana untuk melakukan deteksi dini kanker serviks dengan menggunakan IVA tes serta diharapkan petugas kesehatan dapat memberikan pendidikan kesehatan kepada para wanita mengenai kanker serviks dan cara mendeteksinya sehingga dapat memunculkan kesadaran para wanita dan mengatasi keengganan masyarakat untuk menjalani tes IVA.

\section{DAFTAR PUSTAKA}

Andrijino. Kanker Serviks. Jakarta: Universitas Indonesia; 2009.

Chinthia, Ratnaningsih. Hubungan Tingkat Pengetahuan tentang Kanker Serviks dengan Sikap terhadap Pemeriksaan Papsmear dan IVA pada PUS di Puskesmas Semanu Gunung Kidul. Jurnal Permata Indonesia. 2015; Vol 6 No 2:64.

Eva, Anna. Pengetahuan tentang Faktor Resiko, Perilaku, dan Deteksi Dini Kanker Serviks dengan Inspeksi Visual Asam Asetat (IVA) pada Wanita di Kecamatan Bogor Tengah, Kota Bogor. . Buletin Penelitian Kesehatan.193-202.

Gondowardojo, Wirakusama. Tingkat Pengetahuan, Sikap, dan Perilaku Ibu Mengenai Pemberian Imunisasi Dasar Pada Bayi di Wilayah Kerja Puskesmas Bebandem Tahun 2014. 2014:10.

Hermanto, W A, Suyanto. Hubungan Pengetahuan dan Sikap Terhadap Tindakan Wanita Pekerja Seksual Tidak Langsung di Hotspot $\mathrm{X}$ Kecamatan Tenayan Raya Pekanbaru tentang Pap Smear dan IVA Sebagai Deteksi Dini Kanker Serviks. JOM FK. 2016; Vol 3 No 1:5.

Juanda, Kesuma. Pemeriksaan Metode IVA untuk Pencegahan Kanker Serviks. Jurnal Kedokteran dan Kesehatan. 2015; Vol 2 No 2:169-74.

Kemenkes. Profil Kesehatan Indonesia 2016. Jakarta: Pusat Data dan Informasi Kementerian Kesehatan RI 2017; 2016. 
Kemenkes. Profil Kesehatan Jawa Barat. Jawa Barat: Bidang Pelayanan Kesehatan Dinas Kesehatan Provinsi Jawa Barat; 2012.

Kemenkes. Situasi Penyakit Kanker. Jakarta2015.

Kemenkes. Program Nasional Gerakan Pencegahan dan Deteksi Dini Kanker Leher Rahim dan Kanker Payudara. Jakarta2015.

Lestari. Hubungan Tingkat Pendidikan, Pengetahuan, dan Sikap Ibu Rumah Tangga dengan Perilaku Deteksi Dini Kanker Serviks Metode IVA di Puskesmas Jaten II Kabupaten Karanganyar. . Universitas Sebelas Maret. 2012.

Lestari, Zuraida, Larasati. Hubungan Tingkat Pengetahuan Ibu tentang ASI dan Pekerjaan Ibu dengan Pemberian ASI Eksklusif di Kelurahan Fajar Bulan. Medical Journal of Lampung University. 2013; Vol 2 No 4:96.

Lestari. Hubungan Pengetahuan dan Sikap WUS dengan Perilaku Melakukan IVA di Kelurahan Kotabaru Wilayah Kerja Puskesmas Gondokusuman II Universitas Aisyiyah Yogyakarta; 2016.

Novitasari. Tingkat Pengetahuan Ibu Wanita Usia Subur tentang IVA Test di Dusun Kauman Kragan Gondangrejo Karanganyar Tahun 2014. Surakarta: Stikes Kusuma Husada; 2014.

S. W. Deteksi Dini Kanker Leher Rahim dengan Metode IVA di Wilayah Kerja Puskesmas Ngoresan Surakarta. GASTER. 2011; Vol 8, No 1:681-94.

Utami. Hubungan Tingkat Pengetahuan dengan Perilaku Deteksi Dini Kanker Serviks pada PUS di Wilayah Kerja Puskesmas Sangkrah. Surakarta: Universitas Muhammadiyah Surakarta; 2013

Wawan, Dewi. Teori dan Pengukuran Pengetahuan, Sikap, dan Perilaku Manusia. . Yogyakarta: Nuha Medika; 2010.
Yuliwati. Faktor-Faktor yang Berhubungan dengan Perilaku WUS dalam Deteksi Dini Kanker Leher Rahim Metode IVA di Wilayah Puskesmas Prembun Kabupaten Kebumen Tahun 2012. Depok: Universitas Indonesia; 2012. 